\title{
A COMPARATIVE STUDY ON THE EFFECTIVENESS OF ADDING ROSEMARY AND GINGER EXTRACTS ON MEAT QUALITY DURING FREEZING STORAGE*
}
I. A. Baker
Assistant Prof.
J. E. Alkass
Prof.

Animal Production Dept., College of Agricultural Engineering Science, University of Duhok, Kurdistan Region, Iraq (nljealkas2001@yahoo.com)

\section{ABSTRACT}

The aim of the this experiment was to determine the effect of adding rosemary $(0.05 \%)$ and ginger extracts $(0.5 \%)$ on microbial and oxidative stability in meat lamb stored at $-\mathbf{1 8}^{\circ} \mathrm{c}$ for 150 days. Results revealed that there is steady rise $(p<0.01)$ in microbial count and oxidative rancidity in untreated and treated samples with increasing storage period up to 150 days .Also , a significant $(\mathrm{P} \leq \mathbf{0 . 0 1})$ reduction in all bacteria count $(\mathrm{P} \leq \mathbf{0 . 0 1})$, TBA was observed in samples treated with ginger or rosemary extracts as compared with untreated samples .It was noticed that addition of ginger extract is more effective against formation of TBA than rosemary extract, however no difference exist between them on antimicrobial agent.

Keywords: Lamb patties, Natural Antimicrobial ,Antioxidant, Rosemary Extracts ,Ginger Extracts .

*Part of Ph.D. Dissertation submitted by the first author

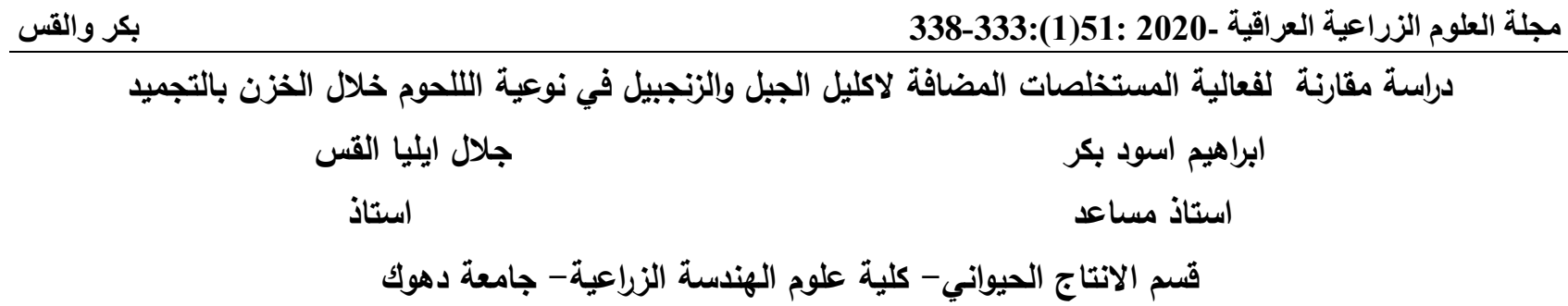

المستخلص

تهاف الاراسة الحالية متابعة تأثير مستخلص كل من اكليل الجبل (0.05\%) والزنجبيل (0.05\%) في منع الاكسدة وتقليل الحمل المايكرويي لاقراص لحم الحملان المخزونة بالتجميد (-18م) لمدة 150 يوما. اشارت النتائج وجود زيادة معنوية (0.01) في العد البكتيري والتزنخ التاكسدي في النماذج المعاملة وغيرالمعاملة بتقدم الخزن لمدة 150 يوم. كما وجد انخفاض معنوي (أ>010) في العد البكتيري وقيم TBA في النماذج المعاملة باكليل الجبل والزنجبيل مقارنة بمعاملة السيطرة. كما تبين بان مستخلص الزنجبيل كان اكثر فعالية من مستخلص اكليل الجبل في خفض قيم TBA في حين كاتت فعاليتها متماثلة في التأثير على العد البكتيري. الكلمات المفتاحية: اقراص لحم الحملان, مضادات الاكسدة والبكتريا الطبيعية, مستخلصات اكليل الجبل والزتجبيل. 


\section{INTRODUCTION}

Meat is the muscle tissue of an animal which is rich in high quality protein, minerals, lipids with a small amount of carbohydrates. Due to its highly perishable nature, they are often very much susceptible to oxidation and microbial attack at any stages of processing, handling and storage (26).It is known that the most common form of chemical deterioration is the oxidation of meat lipids, it is a complex process which depends on chemical composition of meat, light, oxygen access, storage temperatures and may also affected by some technical procedures followed during meat processing (17). Lipid oxidation and microbial growth can be reduced by applying either synthetic or natural antioxidant and antimicrobial agents to the meat products processing to improve its quality, shelf-life and safety (18).Synthetic food additives i.e (butylated hydroxyanisole (BHA), butylated hydroxytoluene (BHT), tertbutylhydroquinone (TBHQ) and propyl gallate (PG)) have been widely used for inhibiting lipid oxidation and microbial growth in meat products due to their strong antioxidant and antimicrobial activities, and their low production cost and easy accessibility (10), however due to the fact that synthetic antioxidant may constitute a potential health hazard for consumers (7),therefore natural antioxidants are used which are obtained mainly from various parts of the plant material like herbs and spices. Among these, the rhizome of the ginger species, (Zinger officinale) is widely used as a spice and food seasoning due to its sweet aroma and pungent taste. It has also been known to have antioxidant activity $(20,33)$ and is effective as antimicrobial $(16,30)$ due to the presence of gingerol and shogaol (15). Also rosemary have been used as successful antioxidants in vacuum packaged raw ground beef and pork (27), cooked ground beef (2), and more effective than a combination of BHA/BHT in raw frozen sausage (29), due to its content certain compound rosmanol, rosmariquinone, rosmaridiphenol, carnosol $(11,13)$. Therefore, the objective of the this study was to compare the potential role of adding ginger and rosemary extracts on inhibition the microbes and oxidation of meat lamb patties during freezing storage.

\section{MATERIALS AND METHODS}

Ginger rhizomes(Zingiber officinal) and rosemary ( $R$. officinalis) were obtained from local market in Duhok. Full details of the extraction methodology and determinations of active compounds was carried out according to Baker et al (5).

\section{Preparations of lamb patties}

The patties was obtained from Karadi lambs carcasses( longissimus dorsi muscle).A combination of salt $(70 \% \mathrm{NaCl}$ and $30 \% \mathrm{KCl})$ based on our previous work (6) was added at a rate of $1.5 \%$ to the minced meat. Then the minced meat was subdivided into three equal parts .Control (C) was formulated without adding plant extracts. The other treatments were prepared by adding the optimum concentrations determined by the tested extracts from our previous study (6). Treatment 2 was blended with $0.05 \%$ rosemary extract (RE),treatment 3 was blended with $0.50 \%$ of ginger extract (GE) and formed into patties $(50 \mathrm{~g})$ using a meat former $(10-\mathrm{cm}$ wide and $1-\mathrm{cm}$ thick each). Patties were placed on plastic foam meat trays, wrapped with polyethylene film and kept in a refrigerator at $18{ }^{\circ} \mathrm{C}$ for 150 days, and evaluated for chemical and microbial count at 1, 60, 90, 120 and 150 days of storage.

\section{Microbial count}

Microbial count(Total plate count, coliform, Psychrophilic bacteria, CFU/g) was determined as recommended by the American Public Health Association for food stuff examination (APHA) (3),. Proteolytic and lipolytic bacterial counts were determined as recommended by Harrigan and MacCance (14).

\section{Analytical methods}

Lipid oxidation as thiobarbituric acid (TBA) was determined according to the method described by Witte et al .,(32). The results were expressed as mg malonaldehyde (MDA) $/ \mathrm{kg}$ meat sample.

\section{Measurement of myoglobin (Mb)}

The concentration of myoglobin in the minced meat was determined as described by krzywicki (19). 


\section{Statistical analysis}

General Linear Model was used to estimate Best Linear unbiased effects (28) of treatment, storage period and their interaction, on all studied traits. Duncan multiple range tests (9) was used to detect significant differences among means of treatment combination (treatments X period)

\section{RESULTS AND DISCUSSION}

\section{Microbial change}

In the present study, results revealed that there is a significant $(\mathrm{p}<0.01) \quad$ steady rise in all bacterial count with increasing storage period up to 150 days from their initial values in control of TPC (39 vs $78 \times 10^{5}$, GE 10.33 $\mathrm{X} 10^{5}$ vs $20.40 \times 10^{5}$, RE $11.5 \times 10^{5}$ vs 20.3 $\mathrm{X} 10^{5}$ ), coliform ( Control 88 vs $141.66 \times 10^{2}$ ,GE $16.66 \times 10^{2}$ vs $30.13 \times 10^{2}$, RE $16 \times 10^{2}$ vs $30.5 \mathrm{X} 10^{2}$ ) , PSY ( control 14.76 vs $70.00 \times 10^{5}$, GE $6.1 \times 10^{5}$ vs $13.4 \times 10^{5}$, RE $6.2 \times 10^{5}$ VS $14.1 \times 10^{5}$,), proteolytic ( control 29.00 vs $62.00 \times 10^{5}$, GE $8.2 \times 10^{5}$ vs 17.6 $\mathrm{X} 10^{5}$, RE $9.2 \times 10^{5}$ vs $\left.16.3 \times 10^{5}\right)$ and lipolytic ( control 27.70 vs $52.00 \times 10^{5}$, GE $9.2 \times 10^{5}$ vs $12.8 \times 10^{5}$, RE $10.33 \times 10^{5}$ vs $14.3 \times 10^{5}$ ), respectively (Table 1 ). Also, the results indicate that addition of rosemary and ginger extracts resulted in significantly $(p<0.01)$ reduction on all counts of studied bacteria . However, it was noticed that there is no significant difference in adding either ginger or rosemary extracts in all studied traits (Table1). The use of natural antimicrobials such as organic acids, essential oils, plant extracts could be considered as a good strategy to inhibit microbial spoilage of meat products (24). The plant extracts and essential oils demonstrated potential antimicrobial effects according to the following mechanisms: (a) The phenolic compounds in these extracts and essential oils affect either enzyme activity or cause protein denaturation . (b) It causes changes in the permeability of microbial cells.(c) It causes changes in the functions of the normal activity of cell membranes such as electron transfer, nutrient exchange, protein synthesis, nucleic acids and enzymatic activity (4). Similarly, it has been shown that added rosemary and ginger have an inhibitions effect on bacteria $(6,30)$ Table (1) Effect of rosemary and ginger extracts on changes in total plate count (TPC), coliform, psychrophlic (PSY), proteolytic, lipolytic count of lamb patties stored at $-18^{\circ} \mathrm{C}$ for 150 days (mean \pm s.e.).

Table 1. Effect of adding rosemary or ginger extracts on changes in total plate count (TPC), coliform, psychrophlic (PSY), proteolytic, lipolytic count of lamb patties stored at $-18^{\circ} \mathrm{C}$ for 150 days (mean \pm s.e)

\begin{tabular}{|c|c|c|c|c|c|}
\hline Parameter & \multicolumn{5}{|c|}{ Storage days at $-18 c$} \\
\hline TPC & 1 & 60 & 90 & 120 & 150 \\
\hline $\mathbf{C}$ & $39.00 \pm 0.57$ e & $45.00 \pm 0.57 \mathrm{~d}$ & $55.00 \pm 0.57$ c & $67.00 \pm 2.3 \mathrm{~b}$ & $78.00 \pm 1.732$ a \\
\hline RE & $11.50 \pm 0.288 \mathrm{i}$ & $12.800 \pm 0.115 h i$ & $14.20 \pm 0.208 h$ & $17.6 \pm 0.173 \mathrm{~g}$ & $20.30 \pm 0.173$ f \\
\hline GE & $10.333 \pm 0.44 \mathrm{i}$ & $\begin{array}{c}14.0 \pm 0.288 h \\
\text { Coliform }\end{array}$ & $15.3 \pm 0.152 \mathrm{hg}$ & $17.60 \pm 0.264 \mathrm{~g}$ & $20.4 \pm 0.173 \mathrm{f}$ \\
\hline C & $88.00 \pm 1.154$ e & $96.666 \pm 0.881 d$ & $115.333 \pm 1.763 \mathrm{c}$ & $125.0 \pm 0.577 b$ & $141.666 \pm 1.452$ a \\
\hline $\mathbf{R E}$ & $16.566 \pm 0.233 \mathrm{j}$ & $19.5 \pm 0.251 \mathrm{i}$ & $26.533 \pm 0.145 \mathrm{~h}$ & $28.733 \pm 0.405$ gfh & $30.50 \pm 0.288 \mathrm{f}$ \\
\hline GE & $16.666 \pm 0.202 \mathrm{j}$ & $19.5 \pm 0.321 \mathrm{i}$ & $26.866 \pm 0.145 \mathrm{~h}$ & $28.033 \pm 0.433 g h$ & $30.133 \pm 0.357$ gf \\
\hline & & PSY & & & \\
\hline C & $14.766 \pm 0.145 \mathrm{e}$ & $25.00 \pm 1.732 \mathrm{~d}$ & $44.0 \pm 2.309 \mathrm{c}$ & $62.0 \pm 0.577 b$ & $70.0 \pm 0.577 a$ \\
\hline RE & $6.20 \pm 0.115 h$ & $7.2 \pm 0.00 \mathrm{~h}$ & $8.60 \pm 0.115 \mathrm{gh}$ & $11.10 \pm 0.200 \mathrm{f}$ & $14.10 \pm 0.200 \mathrm{e}$ \\
\hline GE & $6.1 \pm 0.057 h$ & $\begin{array}{l}6.7 \pm 0.173 \mathrm{~h} \\
\text { Protolytic }\end{array}$ & $7.8 \pm 0.461 \mathrm{~h}$ & $10.40 \pm 0.230 \mathrm{gf}$ & $13.40 \pm 0.230 \mathrm{e}$ \\
\hline C & $29.00 \pm 0.57 e$ & $32.00 \pm 0.57 d$ & $41.00 \pm 0.57 c$ & $44.333 \pm 0.88 b$ & $62.00 \pm 1.154 a$ \\
\hline $\mathbf{R E}$ & $9.200 \pm 0.115 k$ & $11.100 \pm 0.115 j$ & $12.70 \pm 0.057 i$ & $14.2 \pm 0.152 \mathrm{hg}$ & $16.3 \pm 0.152 f$ \\
\hline GE & $8.2 \pm 0.115 k$ & $\begin{array}{c}11.100 \pm 0.404 j \\
\text { liypolytic }\end{array}$ & $12.8 \pm 0.115 h i$ & $14.40 \pm 0.230 \mathrm{~g}$ & $17.6 \pm 0.346 f$ \\
\hline $\mathbf{C}$ & $27.90 \pm 0.17$ e & $34.00 \pm 1.15 \mathrm{~d}$ & $38.00 \pm 1.15 \mathrm{c}$ & $41.00 \pm 1.15 \mathrm{~b}$ & $52.00 \pm 1.154$ a \\
\hline RE & $10.333 \pm 0.333 i h$ & $11.800 \pm 0.115 \mathrm{gh}$ & $12.200 \pm 0.100 \mathrm{gfh}$ & $12.8 \pm 0.200 \mathrm{gf}$ & $14.3 \pm 0.057 \mathrm{f}$ \\
\hline GE & $9.2 \pm 0.986 \mathrm{i}$ & $9.20 \pm 0.230 \mathrm{i}$ & $11.00 \pm 0.500$ gih & $12.10 \pm 0.115 \mathrm{gh}$ & $12.80 \pm 0.152$ gf \\
\hline
\end{tabular}

For each trait, means with different letters within each column and each row differed significantly $(\mathbf{p}<0.01)$. $\mathrm{C}=$ control, $\mathrm{RE}=$ rosemary extract, $\mathrm{GE}=$ ginger extract TBA: The effect of addition rosemary or ginger extracts and storage time on TBA are demonstrated in Table( 2). TBA of patties in

the control , GE , RE started to increase significantly $(\mathrm{p}<0.01)$ from $1.75,0.53,0.64$ at day one to $3.84,1.32,1.58 \mathrm{mg} \mathrm{MDA} / \mathrm{kg}$ meat 
at 150 days ,respectively. It seems from Table (2) that TBA values of the patties with the added either rosemary or ginger extracts were significantly $(\mathrm{p}<0.01)$ lower than control during the entire period of the experiment .Moreover, it was also noticed that the addition of ginger extract is more effective as an antioxidant as compared with the addition of rosemary. Similarly, Formanek et al., (12), Ibrahim et al.,(16), and Abu-almaaly (1) reported that ginger extract as antioxidant was effective against TBA formation when incorporated into meat during frozen storage. This result was consistent with studies in hog sausage (25), and precooked roast beef (22). The antioxidant activity of rosemary extracts was also confirmed by Mathenjwa et al. (21) on pork and beef sausage, which were stored in a frozen state for 180 and 100 days, respectively. such activity of rosemary is due to its content of phenolic primary antioxidants which react with lipid or hydroxyl radicals and convert them into stable products $(23,31)$

\section{Myoglobin (Mb)}

As it is evident from Table (2) that color values in term of myoglobin are decreased significantly $(\mathrm{p}<0.01)$ in all treatments with increasing storage period . Also, it appears from Table (2) that addition of rosemary and ginger extracts resulted in a significantly $(p<0.01)$ higher values of myoglobin as compared with the control . Additionally it was show that rosemary is more effective than ginger in stabilizing color up to 120 days of storage. Similarly, Rojas and Brewer (27) noticed a reduction in color throughout the frozen storage time, regardless of the treatment used. It is known that $\mathrm{Mb}$ loss was due to the oxidation of myoglobin to metamyoglobin, and rosemary retard this process to maintain meat redness longer. Also, a reduction in metamyoglobin formation was noticed and intense red color obtained in fresh beef steaks whose surface was sprayed with rosemary during refrigeration (8).

Table 2. Effect of adding rosemary or ginger extracts to lamb patties on TBA (mg(MDA)/kg meat) and Myoglobin (Mb) (mg /gm meats) values stored at $-\mathbf{1 8}{ }^{\circ} \mathrm{C}$ for 150 days (means \pm s.e.).

\begin{tabular}{|c|c|c|c|c|c|}
\hline Parameter & \multicolumn{5}{|c|}{ Storage days at $-18 c$} \\
\hline TBA & 1 & 60 & 90 & 120 & 150 \\
\hline $\mathbf{C}$ & $1.75 \pm 0.0 d$ & $2.33 \pm 0.004 \mathrm{c}$ & $3.00 \pm 0.03 \mathrm{~b}$ & $3.101 \pm 0.02 b$ & $3.84 \pm 0.004$ a \\
\hline RE & $0.641 \pm 0.00 i$ & $0.868 \pm 0.03 h$ & $1.065 \pm 0.012 g$ & $1.372 \pm 0.051 \mathrm{f}$ & $1.588 \pm 0.013 \mathrm{e}$ \\
\hline GE & $0.533 \pm 0.0138 \mathrm{j}$ & $\begin{array}{c}0.605 \pm 0.010 \mathrm{ji} \\
\mathrm{Mb}\end{array}$ & $0.652 \pm 0.019 i$ & $1.013 \pm 0.000 \mathrm{~g}$ & $1.328 \pm 0.0135 f$ \\
\hline C & $3.93 \pm 0.01 \mathrm{c}$ & $2.54 \pm 0.02 \mathrm{e}$ & $2.30 \pm 0.11 \mathrm{f}$ & $1.257 \pm 0.000 \mathrm{~h}$ & $1.031 \pm 0.0129 \mathrm{i}$ \\
\hline RE & $4.527 \pm 0.0 \mathrm{a}$ & $3.191 \pm 0.015 \mathrm{~d}$ & $2.560 \pm 0.066 \mathrm{e}$ & $1.378 \pm 0.027 \mathrm{~h}$ & $1.05 \pm 0.029 \mathrm{i}$ \\
\hline GE & $4.243 \pm 0.073 b$ & $2.297 \pm 0.020 \mathrm{f}$ & $1.792 \pm 0.068 \mathrm{~g}$ & $1.065 \pm 0.026 \mathrm{i}$ & $1.048 \pm 0.000 \mathrm{i}$ \\
\hline
\end{tabular}

For each trait, means with different letters within each column and each row differed significantly $(\mathbf{p}<0.01)$. $\mathrm{C}=$ control, $\mathrm{RE}=$ rosemary extract, $\mathrm{GE}=$ ginger extract It can be concluded from the results obtained from the current work that adding ginger and rosemary extracts are an effective antioxidant and antimicrobial agents for the control spoilage and extend the shelf life of lamb meat - This study show that ginger was highly effective in reducing lipid oxidation than rosemary but no difference exist between them on their effect as antimicrobial agents. Further studies on the effect of adding together ginger and rosemary on lipid oxidation and microbial count in meat is recommended.

\section{REFERENCES}

1. Abu-almaaly, R. A., 2011. "The Effect of Ginger (Zingiber Officinale) on the Quality Characteristics Of Fresh And Frozen Local Beef Burger" M.Sc. Thesis, College of Education for women, University of Baghdad

2. Ahn, J., I.U. Grun and A. Mustapha, 2007. Effects of plant extracts on microbial growth, color change, and lipid oxidation in cooked beef. Food Micro., 24 (1) : 7-14

3. American Public Health Association (APHA) 1992. Compendium Methods For Microbiological Examination of Foods, 2nd Ed., Washington D.C

4. Aminzare M., M., Hashemi H.H.,Azar and J., Hejazi, 2016. The use of herbal extracts and essential oils as a potential antimicrobial in meat and meat products: A review. Journal of Human, Environment, and Health Promotion, 1(2):63-74

5. Baker, A.I, J. E., Alkass, and H. S., Hussein, 2012a . "Antioxidant and antimicrobial effects of rosemary and ginger extract added to karadi yearling lamb patties" Res. Opin. Anim. Vet.Sci., 2: 109-114 
6. Baker, A.I, J. E., Alkass, and H. S., Hussein, 2012b. "Biochemical, microbial and sensory changes in lamb patties salted with partial replacement of $\mathrm{NaCl}$ and $\mathrm{KCl}$ during Storage", Journal of Animal Scientist, 1(2): 27-31

7. Biswas, A.K., R.C., Keshri, and G.S., Bisht 2004. Effect of enrobing and antioxidants on quality characteristics of precooked pork patties under chilled and frozen storage conditions. Meat Science, 66:733-741.

8. Djenane, D., L., Montanes, and P., Roncales, 2005. "Nuevas perspectivas para la conservacion natural de la carne" Eurocarne 133: $153-180$

9. Duncan, D.B., 1955. "Multiple ranges and Multiple test", Biometric, 11: 16

10. Falowo A.B., P.O., Fayemi, and V., Muchenje, 2014. Natural antioxidants against lipid-protein oxidative deterioration in meat and meat products: A review. Food Research International, 64, 171-181

11. Fernandez-Lopez, J., N., Zhi, L., AlesonCarbonell, J.A. Perez-Alvarez, and V. Kuri, 2005. Antioxidant and antibacterial activities of natural extracts: application in beef meatballs. Meat Sci., 69: 371-380

12. Formanek, Z., J.P., Kerry, F.M., Higgins, D.J., Buckley, P.A., Morrissey, and J.Farkas, 2009. "Investigation on antioxidant and antibacterial activity of some natural extracts", World Journal of Dairy and Food Science, 4:01-07

13. Hac-Szymanczuk, E., J. Roman, and K. Bednarczyk, 2009. A study of the antibacterial activity of rosemary (Rosmarinus officinalis). Nauka Przyr. Technol., 3 (4): 128

14. Harrigan, W.F., and M.E., MacCance, 1976. Laboratory Methods in Food and Dairy Microbiology. Academic press, London

15. Hasan H.A., A.M., Rasheed Raauf B.M., Abd Razik and B.A., Rasool Hassan, 2012. Pharmaceut Chemical Composition and Antimicrobial Activity of the Crude ExtractsIsolated from Zingiber Officinale by Different Solvents. Pharmaceute Anat Acta 3: 184

16. Ibrahim, H.M., A.A., Abou-Arab, and F.M., Abu Salem, 2011. "Antioxidant and antimicrobial effects of some natural plant extracts added to lamb patties during storage", Grasas Y Aceites, 62:139-148
17. Karakaya M., E,Bayrak and K., Ulusoy, 2011. Use of natural antioxidants in meat and meat products. Journal of Food Science and Engineering. 1:1-10.

18. Kim .SJ., S.C., Min HJ., Shin. YJ., Lee. AR., Cho. SY., Kim, and j., Han, 2013. Evaluation of the antioxidant activities and nutritional properties of ten edible plant extracts and their application to fresh ground beef. Meat Science, 93:715-722.

19. Krzywicki, K., 1982. The determination of haem pigment in meat, Meat Sci. 7:29-35

20. Mansour, E.H., and A.H., Khalil, 2000. "Evaluation of antioxidant activity of some plant extracts and their application to ground beef patties", Food Chem., 69:135-141

21. Mathenjwa S.A., C.J., Hugo C., Botha, and A., Hugo, 2012. Effect of alternative preservatives on the microbial quality, lipid stability and sensory evaluation of boerewors. Meat Sci. 91:165-172

22. Murphy, A., J.P., Kerry, J., Buckly, and I., Gray, 1998. "The antioxidant properties of rosemary oleoresin and inhibition of offflavours in precooked roast beef slices", J. Sci. Food Agric., 77: 235-243

23. Naveena, B.M., S., Vaithiyanathan, M.,Muthukumar, A.R., Sen, Y.P., Kumar, M., Kiran, V.A., Shaju, and K.M., Chandran, 2013. Relationship between the solubility, dosage and antioxidant capacity of carnosic acid in raw and cooked ground buffalo meat patties and chicken patties. Meat Science, 95, 195-202

24. Negi P.S., 2012. Plant extracts for the control of bacterial growth: Efficacy, stability and safety issues for food application. International Journal of Food Microbiology, $156,7-17$

25. Newkirk, K.A., C.L., Gilchrist, L.W., Hand, and D.S., Sutton, 1993. "Effects of synthetic antioxidants and rosemary extract on oxidative rancidity and color stability in whole hog sausage", Animal Science Research Report, 79: 78-84

26. Penchalaraju M., D., Lavanya and M.S., Shwetha, 2017. Natural antioxidants to reduce the lipid oxidation process of meat and meat products: A review. International Journal of Chemical Studies 2017; 5(5): 1450-1458

27. Rojas, M.C. and M.S., Brewer, 2008. Effect of natural antioxidants on oxidative 
stability of frozen, vacuum-packaged beef and pork. J. Food Qual., 31 (2): 173-188

28. SAS/STAT, 2002. User Guide for Personal Computers. Release 6.12 SAS. Institute Inc., Cary, NC. U.S.A

29. Sebranek, J.G., V.J.H., Sewalt, K.L., Robbins, and T.A., Houser, 2005. Comparison of a natural rosemary extract and BHA/BHT for relative antioxidant effectiveness in pork sausage. Meat Sci., 69 (6): 289-296

30. Shamsuddeen, U., J.B., Ameh, T.I., Oyeyi, and A.A., Dantata, 2009. "Study on the phytochemical and in vitro antibacterial activity of some spice extracts on some bacteria isolated from meat products", Bayero J. Pure and Applied Sci., 2:101- 104
31. Trindade, R. A., S., Mancini-filho, I.T., Sabundjian, T. C. F., Nunes, V.D., Rogvschi, and A.L.C.H., Villavicencio, 2007. Changes on lipids profile in beef burgers prepared with rosemary extracts and submitted to e-beam processing. INAC, Santos, SP, Brazil 32. Witte,V.C., G.F., Krause, and M.E., Baily, 1970. "A new extraction method for determiniy 2-7 hiobarbiturie acid values of pork and beef during storage", J. Food Sci., 35:582-585

33. Zia-ur-Rehman, A.M., Salariya and F., Habib, 2003. Antioxidant activity of ginger extract in sunflower oil", J. Sci. Food Agric., 83: 624-629 